\title{
A Decade of Synthesis and Modeling in the U.S. Joint Global Ocean Flux Study
}

\author{
Scott C. Doney* \\ Marine Chemistry and Geochemistry \\ Woods Hole Oceanographic Institution \\ Woods Hole MA, 02543 \\ sdoney@whoi.edu \\ 508-289-3776 \\ Fax: 508-457-2193 \\ (* corresponding author) \\ Hugh W. Ducklow \\ School of Marine Science \\ The College of William and Mary \\ Gloucester Point, VA 23062 \\ Submitted to Deep-Sea Research II \\ U.S. JGOFS Synthesis and Modeling Project Special Issue III \\ November 4th, 2005
}

\begin{abstract}
A decade long Synthesis and Modeling Project (SMP) was conducted as the final element of the U.S. Joint Global Ocean Flux Study (JGOFS). The SMP goal was to synthesize knowledge gained from field studies into a set of models that reflect our current understanding of the oceanic carbon cycle. Specific, innovative aspects of the project included the close partnership among scientists conducting field, laboratory, remote sensing, and numerical research and the strong emphasis on data management and web-based, public release of models and data products. Several recurrent science themes arose across the SMP effort including: the development of a new generation of ocean ecosystem and biogeochemistry models that include iron limitation, flexible elemental composition, size structure, geochemical functional groups and particle composition; the application of inverse models and data assimilation techniques to marine food-web data; the creation of whole-ocean synthesis products from the JGOFS global $\mathrm{CO}_{2}$ survey and
\end{abstract}


other studies; and the analysis and modeling of ecosystem and biogeochemical responses to climate and $\mathrm{CO}_{2}$ system perturbations on time-scales ranging from seasonal and interannual variability to anthropogenic climate warming and longer.

Keywords: Marine; Biogeochemistry; Ecology; Modeling

\section{Introduction}

Global climate change due to the build-up of anthropogenic carbon dioxide $\left(\mathrm{CO}_{2}\right)$ in the atmosphere is one of the most challenging environmental problems confronting our society, in part because of the long time-scales for both environmental and human impacts (inter-generational), the complexity of mitigation solutions, and the intimate intertwining of carbon based fossil-fuels in the modern economy. The role of ocean carbon sinks for anthropogenic $\mathrm{CO}_{2}$ and the potential responses and feedbacks of the natural carbon cycle on atmospheric $\mathrm{CO}_{2}$ are some of the key uncertainties surrounding future climate change (Sarmiento and Gruber, 2002). To address such questions, the Joint Global Ocean Flux Study (JGOFS) developed as coordinated, international ocean biogeochemical research program that included numerous process studies, time-series stations, remote sensing, and a global ocean survey. In 1996, U.S. JGOFS initiated as its final component a Synthesis and Modeling Project (SMP) to "synthesize knowledge gained from U.S. JGOFS and related studies into a set of models that reflect our current understanding of the oceanic carbon cycle" (Sarmiento and Armstrong, 1996).

Over nearly a decade, U.S. JGOFS SMP contributed to major advances in our understanding of the ocean carbon system and its past, present and potential future behavior (Doney et al., 2002). Over the project life, a total of 65 grants were funded from 
NSF, NASA, NOAA, and DOE with about 125 distinct co- and principal investigators and numerous students and post-doctoral scientists. In addition to individual research grants, the project facilitated cross-group interactions through annual science meetings, targeted topical workshops, joint cross-group science projects, and infrastructure development (e.g., the SMP data management system and Live Access Server; Glover et al., 2006). Unique aspects of the SMP included: dedicated resources for synthesis activities, model development and model-data fusion; strong synergistic interactions across traditional sub-discipline boundaries (e.g., field and numerical scientists), and creation and support of a larger, active community of scientists focused on marine biogeochemistry. Many important SMP outcomes resulted from ideas generated at the annual science meetings and/or were unfunded community efforts beyond the scope of individual PIs and grants.

Scientific synthesis became a pervasive element of JGOFS achievements. The scientific results of the SMP have been reported in numerous individual research papers and by the interactive web-based data management system (http://usjgofs.whoi.edu/mzweb/syn-mod.htm) that allows access to model code, synthetic data sets and model results generated within the project. A selection of SMP research is documented in this volume (Deep-Sea Research II, Vol. X, No. x-x, 2006) and two prior Deep-Sea Research II special SMP volumes (DSR II, Vol. 49, No. 1-3, 2002 and DSR II, Vol. 50, No. 22-26, 2003). The major JGOFS Process Studies and Time Series programs also have had Deep-Sea Research II synthesis volumes. Below we discuss the papers in this volume and other key SMP papers to illustrate some of the 
recurrent science themes that emerged from the SMP. Given the size and scope of SMP, this brief overview cannot be exhaustive.

\section{Synthesis and Modeling Science Themes}

Ecosystem and Food-web Dynamics

Many of the SMP research projects focused on the development of improved conceptual and numerical models for upper ocean marine ecosystem dynamics. The canonical model of the early JGOFS era was the phytoplankton-zooplankton-nutrientdetritus model of Fasham et al. (1990). JGOFS observations and the increasing sophistication of ocean biologists and chemists demanded more inclusive and diverse approaches to modeling ocean biogeochemical systems (Doney, 1999).

Several different pathways were followed. For example, Laws et al. (2000) created a model with both a traditional export system dominated by large phytoplankton and grazers and a microbial recycling component to examine the conditions under which the export efficiency of the upper ocean is maximized. They used a novel approach, optimizing ecosystem resiliency to small perturbations to tune their model to different environmental forcing scenarios. They showed that in general, export efficiency is maximized at low temperature and high primary production - i.e., at high latitudes in the northern hemisphere and in the Antarctic Polar Front Zone.

Other SMP investigators focused on the need for improved representations of multielement cycling and export in models of ocean biogeochemistry. One approach is to include diverse geochemical functional groups (e.g., calcifiers, silicifiers, N-fixers, etc.) in models (Iglesias-Rodriguez et al., 2002), with independent growth and nutrient uptake 
behavior for the different groups (e.g., Moore et al., 2002a; Moore et al., 2004). Hood et al. (2006) provide a comprehensive review of the topic and detail the state of the art at representing all the major functional groups. A complementary tack has been to break the fixed Redfield (C:N:P) ratios that characterized earlier models, allowing variability among the ratios to better simulate observed remineralization ratios and other departures from Redfield stoichiometry under different nutrient and light stress conditions. Green and Sambrotto (2006) demonstrated the controls exerted by phytoplankton community succession on the elemental ratios in the particle export at the Antarctic Polar Front Zone. This type of variable composition modeling approach can be extended to $\mathrm{Chl}: \mathrm{C}$ ratios and photoadaptation or photoacclimation as well, thus providing a better link between model predicted quantities and observations (in this case the extensive in situ bio-optical and satellite remote sensing data sets) (Armstrong, 2006).

Although the link between iron limitation and High-Nitrate Low-Chlorophyll (HNLC) regions was identified prior to the SMP, it was not until the SMP era that iron dynamics and iron limitation became a common element of marine ecosystem models (e.g., Moore et al. 2002b; Moore et al., 2004; Mongin et al., 2006; Wang et al., 2006; Wiggert et al., 2006). Iron limitation lowers phytoplankton growth rates and alters community structure, tending to shift ecosystems away from the larger diatoms that differentially contribute to vertical export flux. Mongin et al. (2006) adopt a flexiblecomposition structure to model plankton dynamics at the KERFIX site, including independent formulations for iron, carbon, nitrogen and silica. One outcome of including iron limitation in this an other models is that the HNLC condition can be simulated accurately with more realistic grazing losses. 
Inverse models and data assimilation

Validation of marine ecosystem models is difficult and often incomplete because of the lack of information on key stocks and rates, even from the most data-rich field sites. Perhaps the most memorable quote of the SMP came from John Steele (Woods Hole Oceanographic Institution), who mused on how we should avoid generating "false models tested by inadequate data."

In an attempt to avoid this pitfall, Daniels et al. (2006) and Richardson et al. (2006) used an inverse approach to construct best-estimates for specified carbon and nitrogen flow networks containing the key components measured in various JGOFS and other field studies. In their approach, the aggregate flows between model compartments are minimized, a strategy that tends to even out diverging flow magnitudes (large flows get smaller and small ones larger). The resulting food-web solutions provide estimates for flows not measured in the field and the overall pathways of mass and energy through the ecosystem. The resulting insights are not always readily discernable for the observations. However, some care is required because the underlying assumptions about how ecosystems function used in the inverse analysis can generate strikingly different behavior from the same observational data.

Friedrichs et al. (2006) present an alternative model-data fusion approach with variational data assimilation. They utilize a 1-D adjoint model to optimize model parameters for a hierarchy of ecosystem simulations of increasing complexity (e.g., plankton size classes) for the JGOFS time-series data in the Arabian Sea. They find that when model parameters are optimized, more complicated ecosystem models do not 
necessarily give either a better fit or predictive skill for bulk biogeochemical properties (chlorophyll, zooplankton biomass, nitrate, primary and export production).

\section{Remote Sensing}

The SeaWiFS satellite ocean color sensor was launched towards the end of the U.S.

JGOFS field programs (McClain et al., 2004), and the SeaWiFS data played a pivotal role in the SMP in a variety of ways. Carr et al. (2006) use SeaWiFS data to drive a suite of empirical and semi-diagnostic ocean color based primary productivity algorithms. They find a large range in predicted productivities across the algorithms for eutrophic conditions, cold temperatures, Southern Ocean and other HNLC conditions despite the fact that many of the algorithms were tuned based on the same limited in-situ productivity and biooptical data set from the SIMBIOS project. Many of the differences can be attributed to the parameterization of temperature and nutrient effects, not biooptical algorithm complexity. General circulation model-based ecosystem simulations predict a similar global mean productivity as the satellite based estimates but with significantly different regional patterns.

Gardner et al. (2006) present another application of SeaWiFS data to map the global seasonal and spatial patterns of particulate organic carbon (POC). They build an empirical model to relate diffuse attenuation coefficient at $490 \mathrm{~nm}$ measured from the satellite to an extensive in situ data set for particulate beam attenuation. Region-specific regressions are then used to create global maps of particle distributions and POC:Chl ratios. The latter may used to infer phytoplankton physiological state and the relative contributions of autotroph biomass to detrital material. 
Particle Export, Remineralization, and Sediment Biogeochemistry

During the SMP, there was a growing recognition that the biogeochemistry of the aphotic zone depends upon the composition, not just the magnitude, of the particle flux leaving the surface euphotic zone and reaching the deep ocean (Francois et al., 2002). Armstrong et al. (2002), for example, present a "ballast model" where the vertical flux of organic matter through the thermocline and reaching the sediments is enhanced by association with so-called ballast materials (e.g., calcite, silica, dust).

The coupling of organic and inorganic carbon biogeochemistry extends into the surface sediments. Martin and Sayles (2006) use pore water data to show that a significant amount of sediment organic matter remineralization occurs within the sediments and that the depth-scale of remineralization decreases (shortens) as the rain rate of organic matter increases. Organic matter remineralization lowers $\mathrm{pH}$ and tends to enhance calcium carbonate dissolution even when the overlying bottom waters are supersaturated. The spatial variation in depth-scale appears to have important implications for the basin-scale distributions of calcium carbonate dissolution.

\section{Global Ocean $\mathrm{CO}_{2}$ Survey Synthesis and Ocean Carbon Models}

The WOCE/JGOFS global ocean survey provided a wealth of information on the distribution of inorganic carbon system parameters, nutrients, oxygen and other chemical tracers. As part of the SMP, an extensive synthesis effort was carried out via the GLobal Ocean Data Analysis Project (GLODAP; http://cdiac.esd.ornl.gov/oceans/glodap/Glodap_home.htm) (Key et al., 2004). This has 
resulted in a number of papers quantifying, for example, the distribution of anthropogenic $\mathrm{CO}_{2}$ (Sabine et al., 2004), the water-column remineralization of calcium carbonate dissolution (Feely et al., 2004), and the role of the Southern Ocean in controlling nutrient distributions and low latitude productivity (Sarmiento et al., 2004a).

The global survey data also serve as an important evaluation data set for ocean carbon models. The Ocean Carbon Model Intercomparison Project (OCMIP; http://www.ipsl.jussieu.fr/OCMIP/) was an international effort to assess the skill of the current generation of ocean carbon models, and the U.S. OCMIP was a component of the SMP. Model-data comparisons have been used to demonstrate that the current generation of models contains significant errors in simulated physical (Doney et al., 2004a) and tracer based (Matsumoto et al., 2004) skill metrics. The global $\mathrm{CO}_{2}$ survey data are a key element in an iterative cycle of model improvement and testing.

\section{Climate Variability and Climate Change}

Regional studies of climate variability on interannual to decadal time-scales can be used to generate important insights on how marine ecosystems and biogeochemistry respond to physical and chemical perturbations (Boyd and Doney, 2002). A number of SMP modeling studies have focused on coupled biological-physical variability in the tropical oceans. Wang et al. (2006) explore the magnitude and variability in new production along the equatorial upwelling band in the Pacific. In their simulations, they observe ENSO driven modulation of new production in the central and western HNLC regions associated with mixed layer nitrate and iron concentrations and the depth of the thermocline. Wiggert et al. (2006) conduct a similar numerical analysis for the tropical 
Indian Ocean. A main finding is strong spatial and temporal variations in surface bioavailable iron levels caused by both the patterns in atmospheric dust deposition and circulation.

The magnitude and mechanisms of biogeochemical variability in temperate and subtropical regions are not as well resolved as those in the tropics. Using data from the U.S. JGOFS time-series stations near Bermuda (BATS) and Hawaii (HOT), Brix et al. (2006) explore the hypothesis that higher nutrient inputs favor a larger export fraction of net primary production under subtropical, oligotrophic conditions. While differences in nutrient inputs can explain the relative magnitude of annual mean export production between the two sites, they find no clear relationship for interannual variability in export at the individual sites. This suggests that we have limited predictability of export based on our current set of simple conceptual models.

The feedbacks between ocean biogeochemistry and future climate change are not well understood and depend upon the complex responses of the natural ocean ecosystems and the carbon system to changes in ocean circulation, dust deposition, ocean $\mathrm{pH}, \mathrm{UV}$ radiation, ocean acidification and other factors (Boyd and Doney, 2003). Using output from several coupled ocean-atmosphere climate models, Sarmiento et al. (2004b) find that surface phytoplankton biomass and primary production patterns may change significantly due to warming and stratification over the $21^{\text {st }}$ century. In their analysis, the ecological responses to physical climate change are governed by the poleward shift of large-scale biological provinces (e.g., a retreat of the seasonal ice zone) and differed between nutrient and light limited regimes. Ocean acidification and the resulting 
deleterious effects on calcifying organisms are also emerging as major uncertainties for projecting the future state of marine ecosystems (Feely et al., 2004; Orr et al., 2005).

\section{Lessons Learned and Future Research Directions}

The U.S. JGOFS Synthesis and Modeling Project fostered a new "social model" for conducting ocean science, one that is being closely examined and adopted by other environmental research communities and the next generation of ocean biogeochemical programs (e.g., Ocean Carbon and Climate Change Program; Doney et al., 2004b). Specific innovative aspects included the close partnership among scientists conducting field, laboratory, remote sensing, and numerical research and the strong emphasis on data management and web-based, public data release. By any number of measures, the SMP project was a great success. Investigators generated a tremendous number of new insights about marine biogeochemistry; topical workshops highlighted new paradigms, major unknowns and future research needs (e.g., Iglesias-Rodriquez et al., 2002); and the annual science meeting became a preferred forum for exchange of scientific results. The collected suite of synthetic data sets, model code and numerical solutions now being disseminated via the JGOFS data management system is a key long-term legacy of the project and a valuable resource for the broader oceanographic community.

Our basic understanding of ocean biogeochemistry has improved dramatically over the JGOFS era (e.g., Fasham et al., 2001; Buesseler, 2001; Fasham, 2003). Yet many critical questions remain unresolved. Some issues would sound very familiar to the planners of the earliest JGOFS experiments. For example, there is still considerable uncertainty about the seasonal to interannual variability of air-sea $\mathrm{CO}_{2}$ flux or how 
oceanic $\mathrm{CO}_{2}$ uptake is likely to evolve over the next several centuries as ocean circulation and ecology change under greenhouse warming and other global environmental perturbations. In some cases we are still uncertain of even the sign of physical and ecological changes to come. Other problems, while not necessarily all new, are currently receiving more attention. These include the ecological responses to higher $\mathrm{CO}_{2}$ and lower $\mathrm{pH}$, roles of dissolved organic matter and microbial foodwebs, biogeochemical transformations in the mesopelagic ocean, coastal eutrophication, coupling between the open-ocean and continental margins, and the scientific underpinnings for deliberate carbon mitigation strategies such as direct $\mathrm{CO}_{2}$ injection and iron fertilization.

Addressing these questions requires integrated research efforts on a variety of fronts, ranging from monitoring the temporal evolution of the ocean inorganic carbon inventory to innovative process studies of poorly understood biological and chemical dynamics (Doney et al., 2004b). Many of the needed research components are already in place as part of ongoing ocean carbon observing programs (Table 1). Following the dramatic success of the satellite-mounted SeaWiFS ocean color sensor, data are now available from the MODIS instruments and other sensors. In the future, ocean color data will become an operational product from the NPOESS satellite-mounted instruments. A series of targeted, mid-sized ocean biogeochemical process studies have been completed or are underway, and plans are in place for deploying an extensive new ocean observing infrastructure as part of the NSF-sponsored Ocean Research Interactive Observatory Networks (ORION) (http://www.orionprogram.org/). ORION is likely to include a regional cabled network, coastal observatories and open-ocean mooring systems. But no 
strategy is yet articulated for equipping each ORION site with modeling capability or providing the analysis and synthesis tools needed to add value to the new observations.

Despite near-term advances in in situ measurements and remote sensing, ocean observations alone will remain too sparse to fully characterize the relevant time-space variability of marine biogeochemistry (Dickey, 2003). Numerical modeling, including data assimilation, therefore, will continue to play a pivotal role in data synthesis and interpretation. In a break with the past, the development of field experiments should make use, from the start, of a backbone of long-term ocean observing system elements, satellite remote sensing, advanced numerical models and data assimilation. Modeling considerations also should be incorporated from the beginning in the creation of a global observational strategy and process studies, with particular focus on sampling network design, timely public access to data, and collection of field data specifically to address known model deficiencies. Many outstanding questions involve predicting the future, questions that can only be answered with prognostic models. The improvement of prognostic models must therefore be an ongoing focus. As a scientific community, we also need to produce, on a more routine basis, data and model products suitable for decision support by both the public and policy makers (Dilling et al., 2003).

A key attribute contributing to JGOFS's success was the support provided for project and data management from the start of the program. Personal computer processing capabilities and Internet-based communications evolved from primitive levels in the mid1980s to the global, high-speed network linking investigators, computers and data 
archives we take for granted today. Because of the rapid, and in many cases, qualitative changes in information flow experienced during JGOFS, many data management and data access tools were not available to most investigators until relatively late in the program, as the SMP began to take shape (Glover et al., 2006). Enhanced data submission and access will make real-time ocean nowcasting and forecasting a routine feature of most future programs.

Concepts and tools developed in the SMP will be a critical part of this next generation of integrated observational and numerical oceanography. The previous large-scale geochemistry program (GEOSECS) could be synthesized by a handful of visionary individuals (e.g., Broecker and Peng 1982). This may never happen again.

\section{Acknowledgements}

We wish to thank the members of U.S. JGOFS Project and Data Management Offices M. Zawosky, K. Buesseler, C. Chandler, and D. Glover and the many individuals who have contributed to the management effort for the Synthesis and Modeling Project including J. Sarmiento, R. Armstrong, R. DeConto, J. Kleypas, S. Hankin, C. Sabine, I. Lima, and J. Dusenberry. The Synthesis and Modeling Project benefited greatly from the advise, support, and encouragement from the chairs and members of the U.S. JGOFS Scientific Steering Committee and numerous program managers at NSF, NASA, NOAA, and DOE. The U.S. JGOFS SMP management effort was supported by grants from the National Science Foundation (NSF/NCAR 97-142 and NSF OCE-0335589). 
Table 1: A selection of recent and ongoing U.S. ocean carbon research elements (see also Ocean Carbon and Climate Change (OCCC) Program, Doney et al., 2004b).

Global Ocean Carbon Surveys

CLIVAR/ $\mathrm{CO}_{2}$ Repeat Hydrography Program

http://ushydro.ucsd.edu/

Volunteer surface water $\mathrm{pCO}_{2}$ observations

http://www.aoml.noaa.gov/ocd/gcc/index.php http://www.pmel.noaa.gov/co2/uwpco2/

http://www.ldeo.columbia.edu/res/pi/CO2/

Time-series

Hawaii Ocean Time-series (HOT)

http://hahana.soest.hawaii.edu/hot/hot.html

Bermuda Atlantic Time-Series Study (BATS) http://www.bbsr.edu/cintoo/bats/bats.html Carbon Retention in a Colored Ocean (CARIACO)

http://www.imars.usf.edu/CAR/index.html

Monterey Bay Time Series http://www.mbari.org/bog/Projects/CentralCal/intro.htm

Remote Sensing

NASA Ocean Color Research Team (SeaWiFS and MODIS)

http://oceancolor.gsfc.nasa.gov/

\section{Mid-sized Process Studies}

EDdies Dynamics, MIxing, Export, and Species composition (EDDIES) http://science.whoi.edu/users/mcgillic/eddies/EDDIES_Project.html

Mediterranean Flux (MedFlux) http://www.msrc.sunysb.edu/MedFlux/

Southern Ocean Flux Experiment (SOFeX) http://www.mbari.org/expeditions/SOFeX2002/

VERtical Transport In the Global Ocean (VERTIGO)

http://www.whoi.edu/science/MCG/cafethorium/website/projects/vertigo.html

National and International Coordination

U.S. Ocean Carbon and Biogeochemistry Program

http://ocb.whoi.edu

U.S. Carbon Cycle Science Program

http://www.carboncyclescience.gov

International Ocean Carbon Coordination Project

http://ioc.unesco.org/ioccp/ 


\section{References}

Armstrong, R., 2006. Nitrogen allocation and photoacclimation in models of aquatic photosynthesis: alternative representations based on optimality. Deep-Sea Res. II, this volume.

Armstrong, R.A., Lee, C., Hedges, J.I., Honjo, S., Wakeham, S.G., 2002. A new, mechanistic model for organic carbon fluxes in the ocean based on the quantitative association of POC with ballast minerals. Deep Sea Res., II, 49, 219-236.

Boyd, P.W., Doney, S.C., 2002. Modelling regional responses by marine pelagic ecosystems to global climate change. Geophys. Res. Lett., 29(16), 53-1 to 53-4, doi:10.1029/2001GL014130.

Boyd, P., Doney, S.C., 2003. The impact of climate change and feedback process on the ocean carbon cycle. Ocean Biogeochemistry, ed. M. Fasham, Springer, 157-193.

Brix, H., Gruber, N., Karl, D., Bates, N., 2006. On the relationships between primary, net community, and export production in subtropical gyres. Deep-Sea Res. II, this volume.

Broecker, W.S., Peng, T.-H., 1982. Tracers in the sea. 690 pp., Eldigio Press, Palisades, New York.

Buesseler. K.O., 2001. Special Issue: JGOFS. Oceanography 14, 5-121. 
Carr, M.E., Friedrichs, M.A.M., Schmeltz, M., Aita, M.N., Antoine, D., Arrigo, K.R., Asanuma, I., Aumont, O., Barber, R., Behrenfeld, M., Bidigare, R., Buitenhuis, E.T., Campbell, J., Coitti, A., Dierssen, H., Dowell, M., Dunne, J., Esaias, W., Gentili, B., Gregg, W., Groom, S., Hoepffner, N., Ishizaka, J., Kameda, T., LeQuere, C., Lohrenz, S., Marra, J., Melin, F., Moore, J.K., Morel, A., Reddy, T.E., Ryan, J., Scardi, M., Smyth, T., Turpie, K., Tilstone, G., Waters, K., Yamanaka, Y., 2006. A comparison of global estimates of marine primary production from ocean color. Deep-Sea Res. II, this volume.

Daniels, R., Richardson, T.L., Ducklow, H.W., 2006. Food web structure and biogeochemical processes during phytoplankton blooms: An inverse model analysis, Deep-Sea Res. II, this volume.

Dilling, L., Doney, S.C., Edmonds, J., Gurney, K.R., Harriss, R., Schimel, D., Stephens, B., Stokes, G., 2003. The role of carbon cycle observations and knowledge in carbon management. Annual Review of Environment and Resources. 28, 521-558, doi:10.1146/annurev.energy.28.011503.163443.

Doney, S.C., 1999. Major challenges confronting marine biogeochemical modeling. Global Biogeochem. Cycles. 13, 705-714.

Doney, S.C., Lindsay, K., Caldeira, K., Campin, J.-M., Drange, H., Dutay, J.-C., Follows, M., Gao, Y., Gnanadesikan, A., Gruber, N., Ishida, A., Joos, F., Madec, G., Maier- 
Reimer, E., Marshall, J.C., Matear, R.J., Monfray, P., Mouchet, A., Najjar, R., Orr, J.C., Plattner, G.-K., Sarmiento, J., Schlitzer, R., Slater, R., Totterdell, I.J., Weirig, M.-F., Yamanaka, Y., Yool, A., 2004a. Evaluating global ocean carbon models: the importance of realistic physics. Global Biogeochem. Cycles. 18, GB3017, doi:10.1029/2003GB002150.

Doney, S.C., Anderson, R., Bishop, J., Caldeira, K., Carlson, C., Carr, M.-E., Feely, R., Hood, M., Hopkinson, C., Jahnke, R., Karl, D., Kleypas, J., Lee, C., Letelier, R., McClain, C., Sabine, C., Sarmiento, J., Stephens, B., Weller, R., 2004b. Ocean Carbon and Climate Change (OCCC): An Implementation Strategy for U.S. Ocean Carbon Cycle Science, UCAR, Boulder, CO, 108pp (http://www.carboncyclescience.gov/occcreport.html).

Doney, S.C., Kleypas, J.A., Sarmiento, J.L., Falkowski, P.G., 2002. The US JGOFS Synthesis and Modeling Project-An introduction. Deep-Sea Res. II, 49, 1-20.

Fasham, M. (ed.), 2003. Ocean Biogeochemistry, Springer, Berlin, 297pp.

Fasham, M.J.R., Balino, B.M., Bowles, M.C., Anderson, R., Archer, D., Bathmann, U., Boyd, P., Buesseler, K., Burkill, P., Bychkov, A., Carlson, C., Chen, C.T.A., Doney, S., Ducklow, H., Emerson, S., Feely, R., Feldman, G., Garcon, V., Hansell, D., Hanson, R., Harrison, P., Honjo, S., Jeandel, C., Karl, D., Le Borgne, R., Liu, K.K., Lochte, K., Louanchi, F., Lowry, R., Michaels, A., Monfray, P., Murray, J., Oschlies, A., Platt, T., 
Priddle, J., Quinones, R., Ruiz-Pino, D., Saino, T., Sakshaug, E., Shimmield, G., Smith, S., Smith, W., Takahashi, T., Treguer, P., Wallace, D., Wanninkhof, R., Watson, A., Willebrand, J., Wong, C.S., 2001: A new vision of ocean biogeochemistry after a decade of the Joint Global Ocean Flux Study (JGOFS), $A M B I O$, Sp. Iss. 10, 4-31.

Fasham, M.J.R., Ducklow, H.W., McKelvie, S.M., 1990. A nitrogen-based model of plankton dynamics in the oceanic mixed layer. J. Mar. Res., 48, 591-639.

Feely, R.A., Sabine, C.L., Lee, K., Berelson, W., Kleypas, J., Fabry, V.J., Millero, F.J., 2004. Impact of anthropogenic $\mathrm{CO}_{2}$ on the $\mathrm{CaCO}_{3}$ system in the oceans. Science, 305(5682), 362-366.

Francois, R., Honjo, S., Krishfield, R., Manganini, S., 2002. Factors controlling the flux of organic carbon to the bathypelagic zone of the ocean. Global Biogeochem. Cycles, 16(4), 1087, doi:10.1029/2001GB001722, 2002.

Friedrichs, M., Hood, R., Wiggert, J., 2006. Ecosystem model complexity versus physical forcing: quantification of their relative impact with assimilated Arabian Sea data, DeepSea Res. II, this volume.

Gardner, W., Mishonov, A.V., Richardson, M.J., 2006. Global POC concentrations from in-situ and satellite data, Deep-Sea Res. II, this volume. 
Glover, D.M., Chandler, C.L., Doney, S.C., Buesseler, K.O., Heimerdinger, G., Bishop, J.K.B., Flierl, G., 2006. The U.S. JGOFS data management experience, Deep-Sea Res. II, this volume.

Green, S., Sambrotto, R., 2006. Plankton community structure and export of C, N, P and Si in the Antarctic Circumpolar Current, Deep-Sea Res. II, this volume.

Hood, R.R., Laws, E.A., Armstrong, R., Bates, N., Brown, C.W., Carlson, C., Chai, F., Doney, S.C., Falkowski, P., Feely, R.A., Friedrichs, M.A.M., Landry, M.R., Moore, J.K., Nelson, D.M., Richardson, T.L., Salihoglu, B., Schartau, M., Toole, D.A., Wiggert, J.D., 2006. Pelagic functional group modeling: progress, challenges and prospects, Deep-Sea Res. II, this volume.

Iglesias-Rodriquez, M.D., Armstrong, R., Feely, R., Hood, R., Kleypas, J., Milliman, J.D., Sabine, C., Sarmiento, J., 2002. Progress made in study of ocean's calcium carbonate budget. Eos 83(34): 365, 374-375.

Iglesias-Rodriguez, M.D., Brown, C.W., Doney, S.C., Kleypas, J., Kolber, D., Kolber, Z., Hayes, P.K., Falkowski, P.G., 2002. Representing key phytoplankton functional groups in ocean carbon cycle models: coccolithophores, Global Biogeochem. Cycles, 16(4), 47-1 to $47-20$, doi:10.1029/2001GB001454. 
Key, R.M., Kozyr, A., Sabine, C.L., Lee, K., Wanninkhof, R., Bullister, J., Feely, R.A., Millero, F., Mordy, C., Peng. T.-H., 2004. A global ocean carbon climatology: Results from GLODAP. Global Biogeochemical Cycles, Vol. 18, GB4031.

Laws, E.A, Falkowski, P.G., Smith, W.O., Ducklow, H., McCarthy, J.J., 2000.

Temperature effects on export production in the open ocean, Global Biogeochem. Cycles, $14,1231-1246$

Martin, W., Sayles, F., 2006. Organic matter oxidation in deep-sea sediments:

Distribution in the sediment column and implications for calcite dissolution, Deep-Sea Res. II, this volume.

Matsumoto, K., Sarmiento, J.L., Key, R.M., Bullister, J.L., Caldeira, K., Campin, J.-M., Doney, S.C., Drange, H., Dutay, J.-C., Follows, M., Gao, Y., Gnanadesikan, A., Gruber, N., Ishida, A., Joos, F., Lindsay, K., Maier-Reimer, E., Marshall, J.C., Matear, R.J., Monfray, P., Najjar, R., Platter, G.-K., Schlitzer, R., Slater, R., Swathi, P.S., Totterdell, I.J., Weirig, M.-F., Yamanaka, Y., Yool, A., Orr, J.C., 2004: Evaluation of ocean carbon cycle models with data-based metrics, Geophys. Res. Lett., 31, L07303, doi:10.1029/2003GL018970.

McClain, C. R., Feldman, G.C., Hooker, S.B., 2004. An Overview of the SeaWiFS Project and Strategies for Producing a Climate Research Quality Global Ocean Biooptical Time Series. Deep-Sea Res. II, 51(1-3), 5-42. 
Mongin, M., Nelson, D.M., Pondaven, P., Treguer, P., 2006. Simulation of upper-ocean biogeochemistry with a flexible-composition phytoplankton model: $\mathrm{C}, \mathrm{N}$ and Si cycling and Fe limitation in the Southern Ocean, Deep-Sea Res. II, this volume.

Moore, J.K., Doney, S.C., Kleypas, J.A., Glover, D.M., Fung, I.Y., 2002a. An intermediate complexity marine ecosystem model for the global domain. Deep-Sea Res., II, 49, 403-462.

Moore, J.K., Doney, S.C., Glover, D.M., Fung, I.Y., 2002b. Iron cycling and nutrient limitation patterns in surface waters of the world ocean. Deep-Sea Res., II, 49, 463-507.

Moore, J.K., Doney, S.C., Lindsay, K., 2004. Upper ocean ecosystem dynamics and iron cycling in a global 3-D model, Global Biogeochem. Cycles, 18, 4, GB4028, 10.1029/2004GB002220.

Orr, J.C., Fabry, V.J., Aumont, O., Bopp, L., Doney, S.C., Feely, R.A., Gnanadesikan, A., Gruber, N., Ishida, A., Joos, F., Key, R.M., Lindsay, K., Maier-Reimer, E., Matear, R., Monfray, P., Mouchet, A., Najjar, R.G., Plattner, G.-K., Rodgers, K.B., Sabine, C.L., Sarmiento, J.L., Schlitzer, R., Slater, R.D., Totterdell, I.J., Weirig, M.-F., Yamanaka, Y., Yool, A., 2005. Anthropogenic ocean acidification over the twenty-first century and its impact on marine calcifying organisms, Nature, 437, 681-686, doi:10.1038/nature04095. 
Sabine, C.L., Feely, R.A., Gruber, N., Key, R.M., Lee, K., Bullister, J.L., Wanninkhof, R., Wong, C.S., Wallace, D.W.R., Tilbrook, B., Millero, F.J., Peng, T.-H., Kozyr, A., Ono, T., Rios, A.F., 2004. The oceanic sink for anthropogenic $\mathrm{CO}_{2}$, Science, 305, $367-$ 371.

Sarmiento, J.L., Armstrong, R., 1997. U.S. JGOFS Synthesis and Modeling Project Implementation Plan, U.S. JGOFS Planning Office, Woods Hole, MA, 73pp.

Sarmiento, J.L., Gruber, N., Brzezinski, M.A., Dunne, J.P., 2004a. High-latitude controls of thermocline nutrients and low latitude biological productivity. Nature, 427, 56-60.

Sarmiento, J., Slater, R., Barber, R., Bopp, L., Doney, S.C., Hirst, A.C., Kleypas, J., Matear, R., Mikolajewicz, U., Monfray, P., Soldatov, V., Spall, S., Slater, R., Stouffer, R., 2004b. Response of ocean ecosystems to climate warming, Global Biogeochem. Cycles, 18, GB3003, doi:10.1029/2003GB002134.

Sarmiento, J.L., Gruber, N., 2002. Sinks for anthropogenic carbon, Physics Today, 55, $30-36$.

Richardson, T.L., Jackson, G.A., Ducklow, H.W., Roman, M.R., 2006. Spatial and seasonal patterns of carbon cycling through planktonic food webs of the Arabian Sea determined by inverse analysis, Deep-Sea Res. II, this volume. 
Wang, X., Christian, J.R., Murtugudde, R., Busalacchi, A.J., 2006. Spatial and temporal variability in new production in the equatorial Pacific during 1980-2003: physical and biogeochemical controls, Deep-Sea Res. II, this volume.

Wiggert, J.D., Murtugudde, R.G., Christian, J.R., 2006. Annual ecosystem variability in the tropical Indian Ocean: Results of a coupled bio-physical ocean general circulation model, Deep-Sea Res. II, this volume. 